Rev. Int. Contam. Ambie. 36 (3) 711-727, 2020

https://doi.org/10.20937/RICA.53442

\title{
COMPARATIVE DISSIPATION OF ANTHRACENE AND PHENANTHRENE IN A PRISTINE TYPIC HAPLUDOLL SOIL
}

\author{
Disipación de antraceno y fenantreno en un hapludol típico en condiciones prístinas
}

\author{
Silvana Irene TORRI ${ }^{1 *}$, Marisol Natalia CABRERA ${ }^{2}$ y Cecilia ALBERTI ${ }^{3}$
}

${ }^{1}$ Cátedra de Química General e Inorgánica, Departamento de Recursos Naturales y Ambiente, Facultad de Agronomía, Universidad de Buenos Aires, Avenida San Martín 4453, C1417DSE CABA, Argentina

${ }^{2}$ Facultad de Ciencias Exactas y Naturales, Universidad de Buenos Aires, Intendente Güiraldes 2160, Ciudad Universitaria, C1428EGA CABA, Argentina

${ }^{3}$ Instituto Nacional de Tecnología Industrial (INTI), Avenida Gral. Paz 5445, B1650 San Martín, Buenos Aires, Argentina

*Author for correspondence: torri@agro.uba.ar

(Received: October 2018, accepted November 2019)

Key words: grass, Lolium perenne, polycyclic aromatic hydrocarbons, spiked soils

\begin{abstract}
Polycyclic aromatic hydrocarbons (PAHs) are of great environmental concern due to their widespread occurrence and persistence. Anthracene and phenanthrene $\left(\mathrm{C}_{14} \mathrm{H}_{10}\right)$ are two priority pollutants that are found in high concentrations in PAHs-contaminated surface soils. The objective of this study was to analyze the capability of endogenous soil microorganisms of a pristine soil of the Pampas region, Argentina, to dissipate two isomers: anthracene and phenanthrene. Nutrient availability and the effects of ryegrass (Lolium perenne L.) on these PAHs' dissipation were also evaluated. After 100 days, both contaminants were significantly degraded in root-free soils by autochthonous microorganisms. L. perenne significantly enhanced microbial degradation. The dissipation of both pollutants in the rhizosphere was accompanied by higher values of total bacteria counts at the end of the experimental period. No biostimulation effect was observed. In all cases, the dissipation of phenanthrene was significantly higher than anthracene. These results point to the important role of indigenous PAH degrading microorganisms, even present in a non-polluted soil.
\end{abstract}

Palabras clave: pastura, Lolium perenne, hidrocarburo aromático policíclico, suelo contaminado

\section{RESUMEN}

Los hidrocarburos aromáticos policíclicos (HAP) constituyen una preocupación ambiental debido a su persistencia en el ambiente. El antraceno y el fenantreno $\left(\mathrm{C}_{14} \mathrm{H}_{10}\right)$ son dos contaminantes prioritarios que se encuentran en altas concentraciones en la superficie de suelos contaminados con HAP. El objetivo de este estudio fue analizar la capacidad de los microorganismos endógenos presentes en un suelo prístino de la región pampeana, Argentina, para disipar dos isómeros: antraceno y fenantreno. También se evaluó el efecto de la disponibilidad de nutrientes y la presencia de pasto inglés (Lolium perenne L.) sobre dicha disipación. Después de 100 días, los microorganismos autóctonos degradaron significativamente ambos contaminantes en los suelos sin plantas. La presencia de $L$. 
perenne incrementó significativamente la degradación microbiana. La disipación de ambos contaminantes en la rizósfera estuvo acompañada por valores más altos de recuentos de bacterias totales al final del ensayo. No se observó efecto de bioestimulación. En todos los casos, la disipación del fenantreno fue significativamente mayor que la del antraceno. Estos resultados indican el importante papel de los microorganismos autóctonos presentes en suelos no contaminados en la degradación de HAP.

\section{INTRODUCTION}

Polycyclic aromatic hydrocarbons (PAHs) are emitted into the environment by natural processes or by anthropogenic emissions (Li et al. 2014, Duan et al. 2015). Once in the air, PAHs can attach to atmospheric particulate matter to be transported over long distances. Due to their acute toxicity and potential mutagenic, teratogenicity and carcinogenic effects on human health, sixteen PAHs have been considered as priority pollutants by both the United States Environmental Protection Agency (USEPA 1977) and the European Environmental Agency (EC 2001, Keith 2014). Over $90 \%$ of total PAHs released to the environment accumulate in soils, which acts as a sink for these compounds (Eom et al. 2007). In Argentina, soil PAH contamination is mainly related to spills of petroleum products.

The Pampas Region is one of the largest temperate prairies of the world. It is located in the Southern Hemisphere, between $32^{\circ}$ to $39^{\circ} \mathrm{S}$ and 56 to $67^{\circ} \mathrm{W}$. This zone covers more than 52 Mha of agriculturally prime quality land, the remaining being either marginally suitable or unsuitable for cropping due to rainfall and slight differences in relief. Crude oil extraction began in the southwest of the Pampas region, Argentina, in 1969. The predominant soils nearby the petroleum extraction region are Entic Haplustolls and deep, coarse textured typic Hapludolls (Torri et al. 2011), with low nitrogen and phosphorus availability for plant growth (Díaz-Zorita and Buschiazzo 2006). The productivity of the zone is first related to soil water content, and then to nutrient availability (Díaz-Zorita et al. 1999). These agroecosystems are known to be more fragile, with longer time needed to recover from disturbances compared with other environments (Noy-Meir 1973, PROSAP/EPSA 2010). Until now, only one accident was officially informed in the southwest Pampas in 2015, due to the spill of $80 \mathrm{~m}^{3}$ of crude oil with a total affected area of $500 \mathrm{~m}^{2}$.

Anthracene and phenanthrene are usually found in high concentrations in PAHs-contaminated soils (Chirakkara and Reddy 2015, Dubrovskaya et al.
2016). Unlike other high-molecular-weight PAHs, these isomers do not pose a risk to human health. However, phenanthrene is mutagenic in bacterial and animal cells, and carcinogenic in rodents (Wilson and Jones 1993), whereas anthracene is highly toxic to wildlife (Cheung et al. 2008). Owing to their chemical structure that resembles certain carcinogenic PAHs, both compounds have been used as models for different environmental studies (Bouchez et al. 1995, Kanaly and Harayama 2000).

Indigenous soil microbial communities may have an adaptive response to the presence of PAHs (Margesin and Schinner 2001, Delille et al. 2004) if they are not limited by environmental conditions or low nutrient availability (Gavrilescu 2005, Nikolopoulou et al. 2013). In recent decades, different plant species began to be used in remediation technologies, mainly because PAHs dissipation in the rhizosphere may be significantly improved in comparison to the bulk soil (Bourceret et al. 2015). The release of root exudates enhances microbial biomass, activity and diversity (Vácha et al. 2010, Martin et al. 2014, Torri et al. 2014). But plant species differ in their root characteristics and exudates. For instance, grass species have a high root surface area compared to dicotyledonous plants, and possess an extensively branched, fibrous root system (Soleimani et al. 2010), which can interact with soil microorganisms (Dzantor et al. 2000). Besides, fine root death provides readily available nutrients, which may also increase the microbial degradation of PAHs (Olson et al. 2003). In the last years, much of the research on PAHs' dissipation in contaminated soils has focused on using organic or inorganic amendments to immobilize pollutants or to increase their water solubility (Fernández-Luqueño et al. 2017, Han et al. 2017, Kong et al. 2018, among others). However, there is not available information concerning the long-term influence of these substances on the ecosystems (Fernández-Luqueño et al. 2017). Autochthonous adapted microorganisms have the advantage of being safe, eco-friendly and economical, apart from preserving soil natural structure and texture (Huang et al. 2004). Besides, they may be more adapted to the particular soil environment 
than non-indigenous commercial microbial inocula (Silva et al. 2009). However, there is a certain controversy about the capacity of indigenous microbial communities to degrade PAHs in contaminated soils. Some researchers indicated that competent degraders may be absent or present at too low abundances to perform remediation, especially if the site was not previously exposed to the contaminant (Sabate et al. 2004, Couto 2010), while others reported that native hydrocarbon-utilizing microorganisms are present in most natural environments, but selectively enrich in contaminated soil (MacNaughton et al. 1999, Nandal et al. 2015, Baruah et al. 2017).

The objective of this study was to analyze the capability of endogenous soil microorganisms of a pristine sandy soil of the Pampas region, Argentina, not previously exposed to any kind of contaminants, to dissipate two isomers (anthracene or phenanthrene) in optimal temperature and water availability conditions, with or without plant (Lolium perenne L.). The influence of nutrient availability was also evaluated.

We hypothesized that the native soil microbial biomass of this pristine soil, not previously exposed to contaminants, was potentially capable of degrading anthracene or phenanthrene in optimal temperature and water conditions. PAHs removal would increase in the presence of $L$. perenne and adequate nutrient availability.

\section{MATERIALS AND METHODS}

\section{Chemicals}

Analytical anthracene ( $95 \%)$ and phenanthrene $(\geq 97 \%$ ) were purchased from Sigma Aldrich Co., Ltd, UK. All the other chemicals used in the study were of analytical purity.

\section{Soil}

The pristine soil selected was a typic Hapludoll (U.S. Soil Taxonomy) of the Pampas Region, Argentina. Sampling was performed near Carlos Casares Town ( $\left.35^{\circ} 37^{\prime} \mathrm{S}-61^{\circ} 22^{\prime} \mathrm{W}\right)$. Composite soil samples (10 sub samples, 0 - $15 \mathrm{~cm}$ depth) were collected from fields with no previous history of contamination, far from roads or urban areas in order to assure minimum concentrations of PAHs. Water holding capacity was determined according to the method proposed by Mizuno et al. (1978). Soil samples (10 sub samples) were thoroughly homogenized, air dried and passed through a stainless-steel sieve with 2-mm openings to remove stones and roots. Relevant soil properties are presented in table $\mathbf{I}$.
TABLE I. SOIL CHARACTERISTICS OF THE TYPIC HAPLUDOLL (A HORIZON, 0-15 CM) USED FOR THE POT EXPERIMENT

\begin{tabular}{lc}
\hline & Typic Hapludoll \\
\hline Clay $(\%)$ & 19.2 \\
Silt $(\%)$ & 23.2 \\
Sand $(\%)$ & 57.6 \\
$\mathrm{pH}$ & 5.12 \\
Organic carbon $(\mathrm{g} / \mathrm{kg})$ & 28.6 \\
Water holding capacity $(\%)$ & 19.3 \\
Total $\mathrm{N}(\mathrm{mg} / \mathrm{g})$ & 2.62 \\
Electrical conductivity $(\mathrm{dS} / \mathrm{m})$ & 0.61 \\
Cation exchange capacity $(\mathrm{cmol} / \mathrm{c}) / \mathrm{kg})$ & 22.3 \\
Exchangeable cations $_{\text {Ca }}{ }^{2+}\left(\mathrm{cmol}_{\mathrm{c}} / \mathrm{kg}\right)$ & \\
$\mathrm{Mg}^{2+}\left(\mathrm{cmol}_{\mathrm{c}} / \mathrm{kg}\right)$ & 10.2 \\
$\mathrm{Na}^{+}\left(\mathrm{cmol}_{\mathrm{c}} / \mathrm{kg}\right)$ & 2 \\
$\mathrm{~K}^{+} \quad\left(\mathrm{cmol}_{\mathrm{c}} / \mathrm{kg}\right)$ & 0.3 \\
\hline
\end{tabular}

\section{Soil spiking procedure}

Soil was spiked with anthracene or phenanthrene. To maintain indigenous microbiota, the soil was not sterilized. Although PAHs are usually added to soils solubilized in different organic solvents (acetone, dichloromethane, hexane), in this work the compounds were added as a fine solid powder. This way was chosen in order to avoid any damage to the natural microflora by the organic solvent (Ruberto et al. 2006). The spiking technique used was stainlesssteel spoon (Doick et al. 2003): $1 \mathrm{~g}$ of anthracene or phenanthrene crystals were finely ground in an agate mortar and added to a mixing vessel containing $200 \mathrm{~g}$ of dry soil, and gentle mixed using a sterile spatula for $5 \mathrm{~min}$. The remainder $800 \mathrm{~g}$ soil was added in $200 \mathrm{~g}$ aliquots; blending was performed for 25 minutes. To ensure a uniform distribution of anthracene or phenanthrene, both spiked soils were each extended in a plastic tray, and replicated soil samples for analysis were taken from different parts of the bulk spiked soil.

\section{Greenhouse experiment}

A pot experiment was conducted in a greenhouse $\left(23 \pm 1{ }^{\circ} \mathrm{C}\right)$ sheltered from rain or direct sunlight. A disc of filter paper was placed in the bottom of each plastic pot (10 cm depth $\mathrm{x} 6 \mathrm{~cm}$ diameter) to avoid soil loss. The pots were filled with $250 \mathrm{~g}$ dry weight spiked or unspiked soils, and were afterwards covered with a layer of $5 \mathrm{~mm}$ of coarse sand to minimize PAHs volatilization (Zhou et al. 2013). Pots were left undisturbed and allowed to settle down over 10 days. During this period, and throughout all the 
experiment, soils were maintained at $80 \%$ WHC using distilled water, preventing possible loss of PAHs due to leaching.

Ryegrass (Lolium perenne L.) seeds were surface sterilized by soaking in $30 \%(\mathrm{v} / \mathrm{v}) \mathrm{H}_{2} \mathrm{O}_{2}$ for $20 \mathrm{~min}$ and washed several times with distilled water. At day 10 , twenty seeds were surface-sown in each pot according to the treatments detailed in table II. In all, 12 treatments [ 1 soil material x 3 (no pollutant, anthracene, phenanthrene) x 2 (plant, no plant) $\mathrm{x}$ 2 (non-fertilized, fertilized)] were each replicated four times. The pots were moved around at regular intervals to compensate for light differences.

TABLE II. TREATMENTS

\begin{tabular}{ll}
\hline Abbreviation & Description \\
\hline $\mathrm{C}$ & non-spiked soil \\
$\mathrm{CF}$ & non-spiked soil with fertigation \\
$\mathrm{CR}$ & non-spiked soil with ryegrass \\
$\mathrm{CRF}$ & non-spiked soil with ryegrass and fertigation \\
$\mathrm{A}$ & anthracene spiked soil \\
$\mathrm{AF}$ & anthracene spiked soil with fertigation \\
AR & anthracene spiked soil with ryegrass \\
ARF & anthracene spiked soil with ryegrass and \\
& fertigation \\
P & phenanthrene spiked soil \\
PF & phenanthrene spiked soil with fertigation \\
PR & phenanthrene spiked soil with ryegrass \\
PRF & phenanthrene spiked soil with ryegrass and \\
& fertigation \\
\hline
\end{tabular}

Germination was monitored closely between days 10-25. The number of germinated seeds in each pot was recorded and expressed as a percentage of the number of seeds added. Seedlings were thinned to ten at day 25 .

At day $25,3 \mathrm{~mL}$ of an aqueous solution made up of $1 \mathrm{~g} / \mathrm{L}$ containing $\mathrm{N}: \mathrm{P}_{2} \mathrm{O}_{5}: \mathrm{K}_{2} \mathrm{O}$ 15:15:15 ratio (Xu et al. 2006) were added twice a week to each pot of the fertilized treatment. To ensure nutrient homogeneous distribution, nutrient solution was uniformly hand applied by drops on soil surface prior to watering. If weeds germinated, they were removed periodically by hand before they reached $0.5 \mathrm{~cm}$ in size. At day 90, the aerial parts of the plants were harvested. Aerial biomass was dried at $60{ }^{\circ} \mathrm{C}$ for $48 \mathrm{~h}$, and then weighed (DW). The soil from each pot was collected and homogenized. Soil samples were stored at $4{ }^{\circ} \mathrm{C}$ before analysis. Since L. perenne's roots explored all the pot's volume, the recovered soils from planted pots were considered as rhizospheric soil, and the others as root-free soil (Chiapusio et al. 2007, Liu et al. 2013).

\section{Anthracene or phenanthrene extraction and quantification}

The procedure described by Torri and Alberti (2012) was used to determine anthracene and phenanthrene concentrations in soil samples. Briefly, $10 \mathrm{~g}$ of soil sample were sonicated 20 min with $20 \mathrm{~mL}$ of hexane:acetone $(3: 2, \mathrm{v} / \mathrm{v})$ in an ultrasonic bath (frequency $35 \mathrm{kHz}$, Neytech $28 \mathrm{H}$, USA), followed by centrifugation at $3000 \mathrm{rpm}$, reduced to $1 \mathrm{~mL}$ with rotary evaporator at $30{ }^{\circ} \mathrm{C}$ and injected into the gas chromatography-mass spectrometry (GC/MS) system. The analysis was carried out with a GCMS-QP2010 equipment from Shimadzu (Shimadzu Corporation, Japan) equipped with a DB-1 fused silica capillary column (polydimethylsiloxane, $30 \mathrm{~m}$ long x $0.25 \mathrm{~mm}$ i.d. $0.25 \mu \mathrm{m}$ film thickness, J\&W Scientific, Folson, CA). The GC system was operated in splitless mode and 1 $\mu \mathrm{L}$ portions of the extracts were injected by using an autosampler. Both the injection liner, which contained deactivated glasswool for splitless injection (Agilent Technologies), and the transfer line were maintained at $280{ }^{\circ} \mathrm{C}$. The oven temperature was programmed to rise from $70{ }^{\circ} \mathrm{C}$ ( $1 \mathrm{~min}$ hold $)$ to $290{ }^{\circ} \mathrm{C}$ at a rate of $30^{\circ} \mathrm{C} / \mathrm{min}$ (22 min hold). Helium was used as the carrier gas at linear velocity $40 \mathrm{~cm} / \mathrm{s}$. The electron-impact (EI) ionization energy was $70 \mathrm{eV}$. The presence of the compounds was confirmed by means of the mass spectra obtained in full scan acquisition mode in the $\mathrm{m} / \mathrm{z}$ range from 20 to 500 . High purity analytical standards ( $>98.5 \%$ ) of anthracene or phenanthrene were injected in triplicate to identify the retention time and mass spectra of each compound. Standard calibration curves were established by plotting peak areas (Fig. 1) against different concentrations of anthracene (range: $3.000-820.000 \mu \mathrm{g} / \mathrm{mL}$ ) or phenanthrene (range: 0.441-66.216 $\mu \mathrm{g} / \mathrm{mL}$ ). Regressive equations for anthracene and phenanthrene were $\mathrm{y}=54070 \mathrm{x}-$ $263065, \mathrm{R}^{2}=0.9962$ and $\mathrm{y}=140532 \mathrm{x}-102291$, $\mathrm{R}^{2}=0.9986$ respectively.

The system was controlled by an interface module and a computer. Mass spectra was compared with reference compounds. The peaks of the total components were integrated to obtain the total area. The area of each compound was divided by the total area and expressed as percentage. The concentration of those that produced a signal-to-noise of 3:1 in blank sample was defined as detection limit (DL). The DL for anthracene and phenanthrene were $2.0 \mathrm{ng} / \mathrm{g}$ (DW) and $2.3 \mathrm{ng} / \mathrm{g}$ (DW) respectively. 

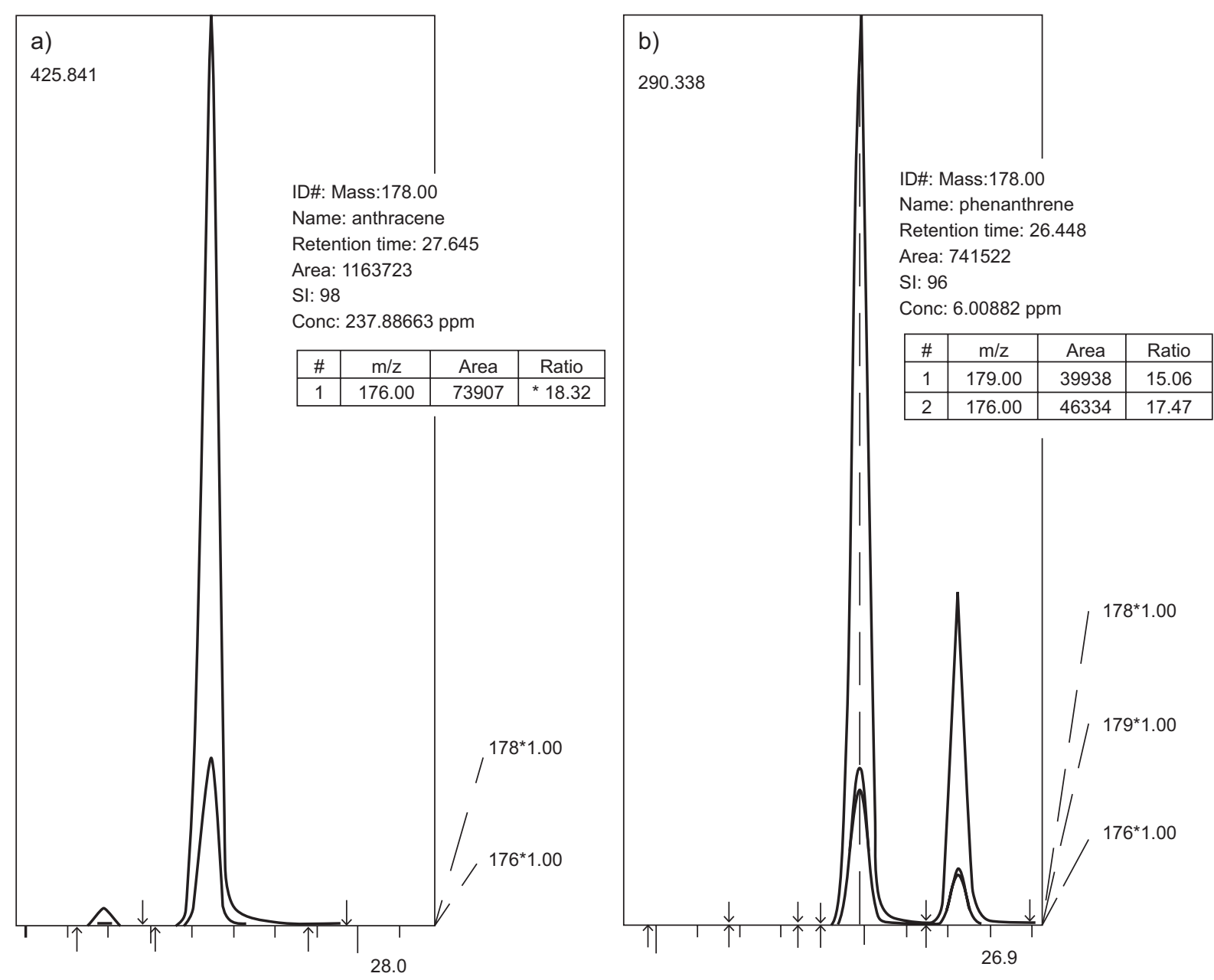

Fig. 1. Quantification of peak areas. A) anthracene; B) phenanthrene

\section{Counting of the total bacterial community}

Ten grams soil samples were added to $100 \mathrm{~mL}$ sterile $0.85 \% \mathrm{NaCl}(\mathrm{w} / \mathrm{v})$ solution, sonicated for 1 min and allowed to stand for $2 \mathrm{~min}$. Ten-fold serial dilutions in the ranges $10^{-1}$ to $10^{-9}$ were prepared (Fawole and Oso 2007). Aliquots $(0.01 \mathrm{~mL}$ ) of these dilutions were seeded on sterile Petri dishes on tryptone soya agar medium in triplicate and incubated in the dark at $30{ }^{\circ} \mathrm{C}$ for 7 days. Uninoculated controls were included. Total heterotrophic bacterial count was determined by pour plate technique, and expressed as colony forming units per gram of dry soil $(\mathrm{CFU} / \mathrm{g})$.

\section{Statistical analysis}

The statistical analysis was performed with Statistix 7.0 (Analytical Software 2000), processing the data for analysis of variance (ANOVA) to test main and interactive effects. Normality assumption was tested by the Shapiro-Wilks test, and homogeneity of variance was tested using the Bartlett's test. Significant effects and interactions between contaminant, plant and fertilizer were evaluated. Where significant $F$ values were obtained, differences between individual means were tested using Tukey's test. Statistical significance was defined as $\mathrm{p}<0.05$. All results reported are the mean of four replicates. The results were expressed as mean \pm standard deviation.

\section{RESULTS}

\section{Soils}

Non-spiked soils had undetectable anthracene and phenanthrene concentrations. In the spiked soils, the initial levels of anthracene and phenanthrene $(1000 \pm 21 \mathrm{mg} / \mathrm{kg}$ and $1000 \pm 29 \mathrm{mg} / \mathrm{kg}$ respectively) met the required coefficient of variance for 
spike-homogeneity for the mixing to be considered valid and statistically sound (Hakanson 1984). Therefore, mean anthracene and phenanthrene concentration measured in the subsamples was assumed to be representative of all the spiked soil (Northcott and Jones 2000). These initial levels $(1000 \pm 21 \mathrm{mg}$ anthracene $/ \mathrm{kg}$ and $1000 \pm 29 \mathrm{mg}$ phenanthrene $/ \mathrm{kg}$ ) represent the mean concentration of both PAHs at day 0 in the greenhouse trial, and may well be its soil concentration after an accidental discharge into the environment (Alvaro et al. 2017).

\section{Effect of PAHs treatments on $L$. perenne growth}

Percentage seed emergence of $L$. perenne (93-95\%) did not significantly vary $(\mathrm{p}<0.05)$ between spiked and non-spiked soils. Plants did not exhibit apparent signs of stress or toxicity along the growing period under PAHs treatment. Soil addition of anthracene $(\mathrm{AR})$ or phenanthrene (PR) resulted in a statistically higher production of aerial biomass compared to the unfertilized control (CR; Table III) in soils (CRF), biomass yield significantly increased with fertigation. However, the aerial biomass yield of the fertilized anthracene spiked soil (ARF) was significantly lower ( $p$ $<0.05)$ than the unfertilized treatment (AR), whereas no statistical differences were observed between fertilized and non-fertilized phenantrene spiked soils (PR vs. PRF). All fertilized treatments (CRF, ARF and PRF) showed no statistical differences in relation to aerial biomass (Fig. 2).

\section{Dissipation of anthracene and phenanthrene in soil \\ GC-MS chromatograms of anthracene and phenanthrene remaining in the soil at the end of the}

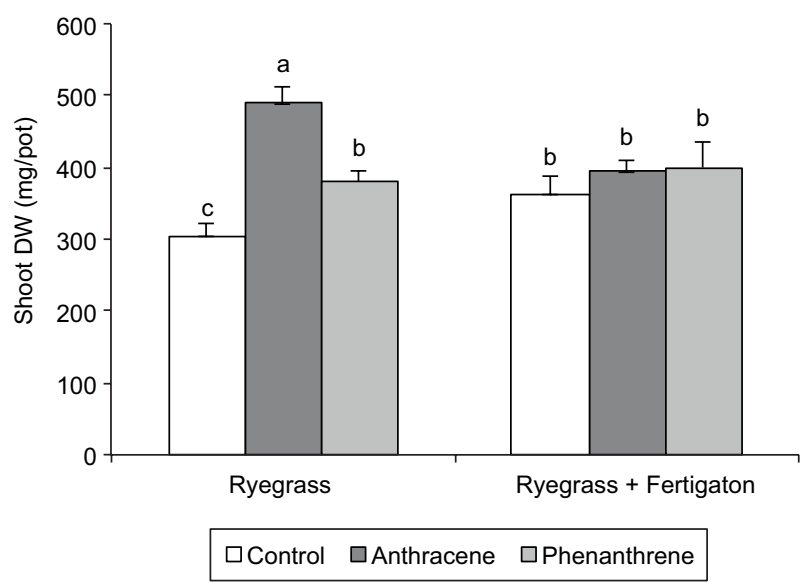

Fig. 2. Aerial biomass (shoot dry weight (DW)) of ryegrass at the end of the experimental period (100 days). Distinctive groups are marked with different letters $(\mathrm{p}<0.05)$

experimental period are shown in figures 3 and 4; their residual concentrations are shown in table III. After 100 days, the mean concentration of both PAHs was significantly reduced in all treatments. Initial anthracene $(1000 \mathrm{mg} / \mathrm{kg}$ soil) and phenanthrene $(1000 \mathrm{mg} / \mathrm{kg}$ soil)were significantly reduced to $331.5 \mathrm{mg}$ anthracene $/ \mathrm{kg}$ soil (A) and $88.4 \mathrm{mg}$ phenanthrene $/ \mathrm{kg}$ soil $(\mathrm{P})$ in unplanted treatments $(\mathrm{p}<0.05)$. This represents a removal efficiency of $66.9 \%$ and $91.2 \%$ respectively.

In planted spiked soils, anthracene and phenanthrene were reduced to 167.5 and $2.74 \mathrm{mg} / \mathrm{kg}$ respectively (treatments AR and PR), representing $83.25 \%$ and $99.7 \%$ depletion. Moreover, the comparison of mean values based on the AOV model statement

TABLE III. INITIAL CONCENTRATION OF ANTHRACENE OR PHENANTHRENE (DAY 0), RECOVERIES AND PERCENT DISSIPATED AFTER 100 DAYS IN EACH TREATMENT

\begin{tabular}{lcccrrrrr}
\hline Treatment* & \multicolumn{3}{c}{$\begin{array}{c}\text { mg pollutant/kg soil } \\
\text { day } 0\end{array}$} & \multicolumn{9}{c}{$\begin{array}{c}\text { mg pollutant/kg soil } \\
\text { day } 100\end{array}$} & \% dissipated \\
\hline A & 1000 & \pm & 21 & 331.45 & \pm & 4.68 & a & 66.90 \\
AF & 1000 & \pm & 21 & 348.60 & \pm & 49.26 & a & 65.14 \\
AR & 1000 & \pm & 21 & 167.51 & \pm & 33.34 & b & 83.25 \\
ARF & 1000 & \pm & 21 & 112.92 & \pm & 6.74 & b & 88.71 \\
P & 1000 & \pm & 29 & 88.40 & \pm & 9.96 & bc & 91.20 \\
PF & 1000 & \pm & 29 & 103.65 & \pm & 9.36 & b & 89.60 \\
PR & 1000 & \pm & 29 & 2.74 & \pm & 0.81 & c & 99.70 \\
PRF & 1000 & \pm & 29 & 0.50 & \pm & 0.11 & c & 99.95 \\
\hline
\end{tabular}

*Treatments: $\mathrm{A}=$ anthracene spiked soil; $\mathrm{AF}=\mathrm{A}$ with fertigation; $\mathrm{AR}=\mathrm{A}$ with ryegrass; $\mathrm{ARF}=\mathrm{A}$ with ryegrass and fertigation; $\mathrm{P}=$ phenanthrene spiked soil $\mathrm{PF}=\mathrm{P}$ with fertigation; $\mathrm{PR}=\mathrm{P}$ with ryegrass; $\mathrm{PRF}=\mathrm{P}$ with ryegrass and fertigation. Distinctive groups are marked with different letters $(\mathrm{p}<0.05)$. 

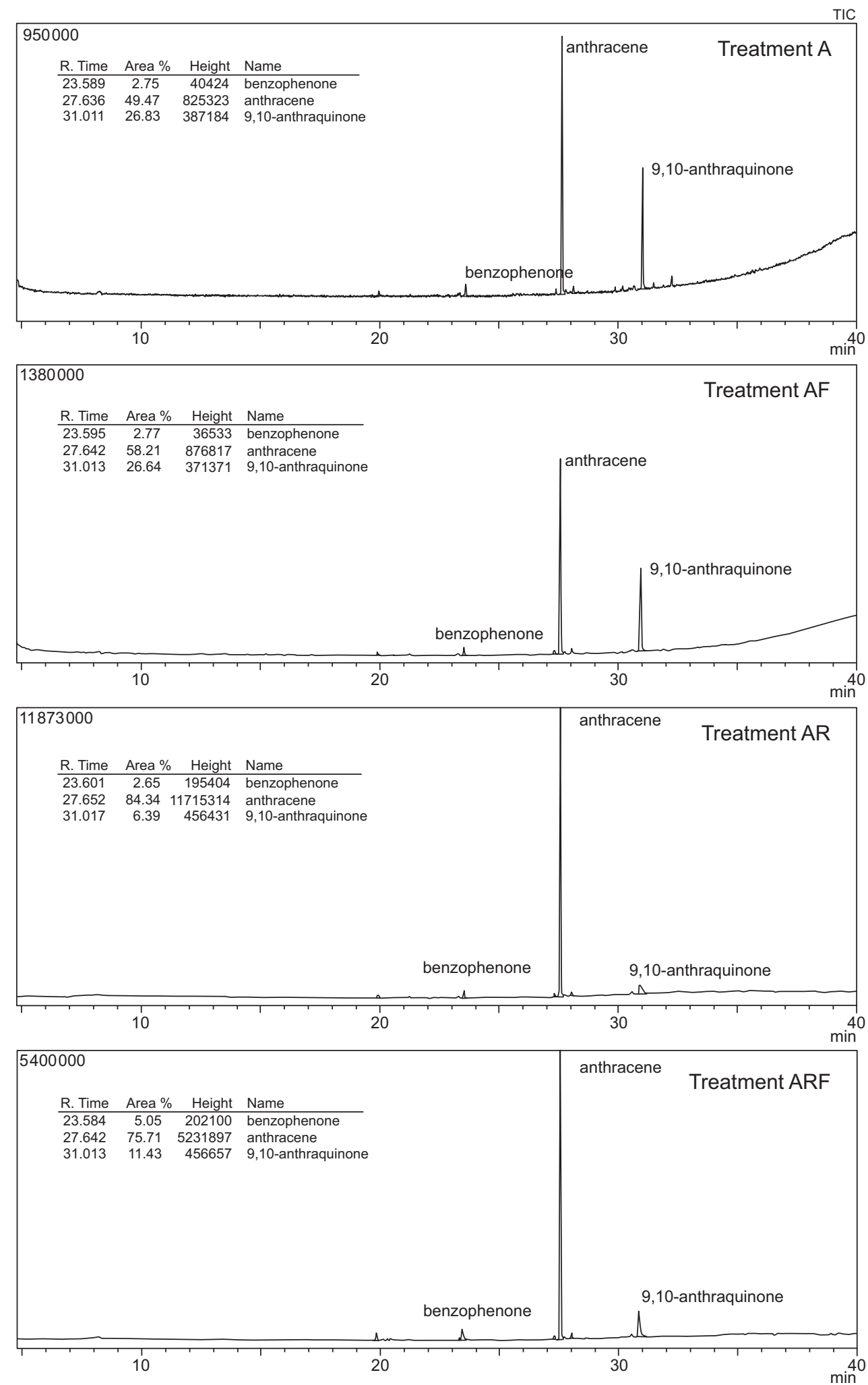

Fig. 3. Total ion chromatogram (TIC) from the gas chromatography-mass spectrometer analysis of anthracene spiked soils at the end of the experimental period. Treatments: $\mathrm{A}=$ anthracene spiked soil; $\mathrm{AF}=\mathrm{A}$ with fertigation; $\mathrm{AR}=\mathrm{A}$ with ryegrass; $\mathrm{ARF}=\mathrm{A}$ with ryegrass and fertigation 
indicated a significant interaction $(\mathrm{p}<0.01)$ between two individual factors: plant and contaminant (Table IV). No other interactions were observed. The addition of nutrients had no effect on both PAHs dissipation: no significant differences in anthracene or phenanthrene soil concentration were observed between fertilized vs non-fertilized treatments (A and AF, AR and ARF, $\mathrm{P}$ and $\mathrm{PF}$ or PR and PRF).

The overall extent of PAHs dissipation was clearly compound-dependent: after 100 days, the concentration of anthracene was significantly higher $(p<0.05)$ compared to that of phenanthrene for the same treatment in all spiked soils (Table III).

\section{Total bacterial count}

Figure 5 shows the mean total bacterial counts in all treatments after the 100 days pot experiment. In the non-spiked soil, bacterial counts significantly increased (Tukey, $\mathrm{p}<0.05$ ) with nutrient addition (CF) or L. perenne planting (CR) as compared to control $(\mathrm{C})$, although no significant differences $(\mathrm{p}$ $>0.05$ ) between CF, CR and CRF were observed.

Soil spiking with anthracene (A) or phenanthrene $(\mathrm{P})$ produced no significant differences $(\mathrm{p}>0.05)$ with respect to bacterial counts relative to the unspiked control. No effect due to nutrients addition was observed in $\mathrm{AF}$ or PF compared to A or Prespectively. However, bacterial counts in the anthracene or phenanthrene spiked soils were significantly higher $(\mathrm{p}<0.05)$ in plant treatments (AR or ARF; PR or PRF) as compared to unplanted treatments (A, AF or P, PF respectively).

\section{DISCUSSION}

Ryegrass (Lolium perenne L.) was chosen as the test plant for phytoremediation to reflect typical species found in the Pampas region. Aerial biomass was measured at the end of the experimental period to explore the ability of $L$. perenne to grow in anthracene or phenanthrene spiked soils.

Toxic effects of both PAHs on the growth of this species have been previously described (Günther et al. 1996, Cheema et al. 2010, Acosta-Santoyo et al. 2017). These authors found that root and shoot yields of $L$. perenne were significantly reduced in PAHspolluted soils compared to control soils. Low-molecular-weight volatile hydrocarbons are soluble in hydrophobic plant materials, and can penetrate root's cell membranes (Salanitro et al. 1997). Phytotoxicity may be exerted in part by PAHs ability to damage cell membranes, reducing nutrient or metabolite transport (Chouychai et al. 2007) or water utilization efficiency (Ma et al. 2010, Nakata et al. 2011). Photosynthetic activity and electron transport may also be inhibited (Mallakin et al. 2002, Torri et al. 2009). These effects are nonspecific, and depend on PAHs water solubility. Reilley et al. (1996) suggested that PAHs might reduce the ability of contaminated soil to provide water and nutrients to plants, leading to a decline in biomass production. PAHs may also induce retard growth, genetic mutation, and increase plant sensitivity to other stresses (Maliszewska-Kordybach and Smreczak 2000).

Contrary to the results reported by other researchers, the presence of anthracene or phenanthrene did not affect seedling emergence of $L$ perenne. Several studies reported that seed germination might be insensitive to bioavailable toxic chemicals because seedlings obtain nutrients from internal materials (Smith et al. 2006, Eom et al. 2007, Torri et al. 2009, Anyanwu and Semple 2015). Surprisingly, plant aboveground biomass (DW) was significantly higher in spiked treatments compared to non-spiked soils,

TABLE IV. ANALYSIS OF VARIANCE OF STUDIED FACTORS (POLLUTANT, PLANT, FERTIGATION) AND PARTITION OF THE TREATMENT SUM OF SQUARES INTO MAIN EFFECT AND INTERACTION

\begin{tabular}{lcccrc}
\hline SOURCE & DF & Sum of squares & Mean square & F & P \\
\hline FERTIGATION (A) & 1 & 1220.88 & 1220.88 & 0.82 & 0.3740 \\
PLANT (B) & 1 & 158727 & 158727 & 106.67 & 0.0000 \\
SPIKED (C) & 1 & 273945 & 273945 & 184.10 & 0.0000 \\
AxB & 1 & 2062.97 & 2062.97 & 1.39 & 0.2506 \\
AxC & 1 & 2846.63 & 2846.63 & 1.91 & 0.1794 \\
BxC & 1 & 17262.9 & 17262.9 & 11.60 & 0.0023 \\
AxBxC & 1 & 427.584 & 427.584 & 0.29 & 0.5969 \\
RESIDUAL & 24 & 35711.8 & 1487.99 & & \\
TOTAL & 31 & 492204 & & & \\
\hline
\end{tabular}

$\mathrm{DF}=$ degrees of freedom; $\mathrm{F}=\mathrm{F}$-statistic $; \mathrm{P}=\mathrm{P}$-value 

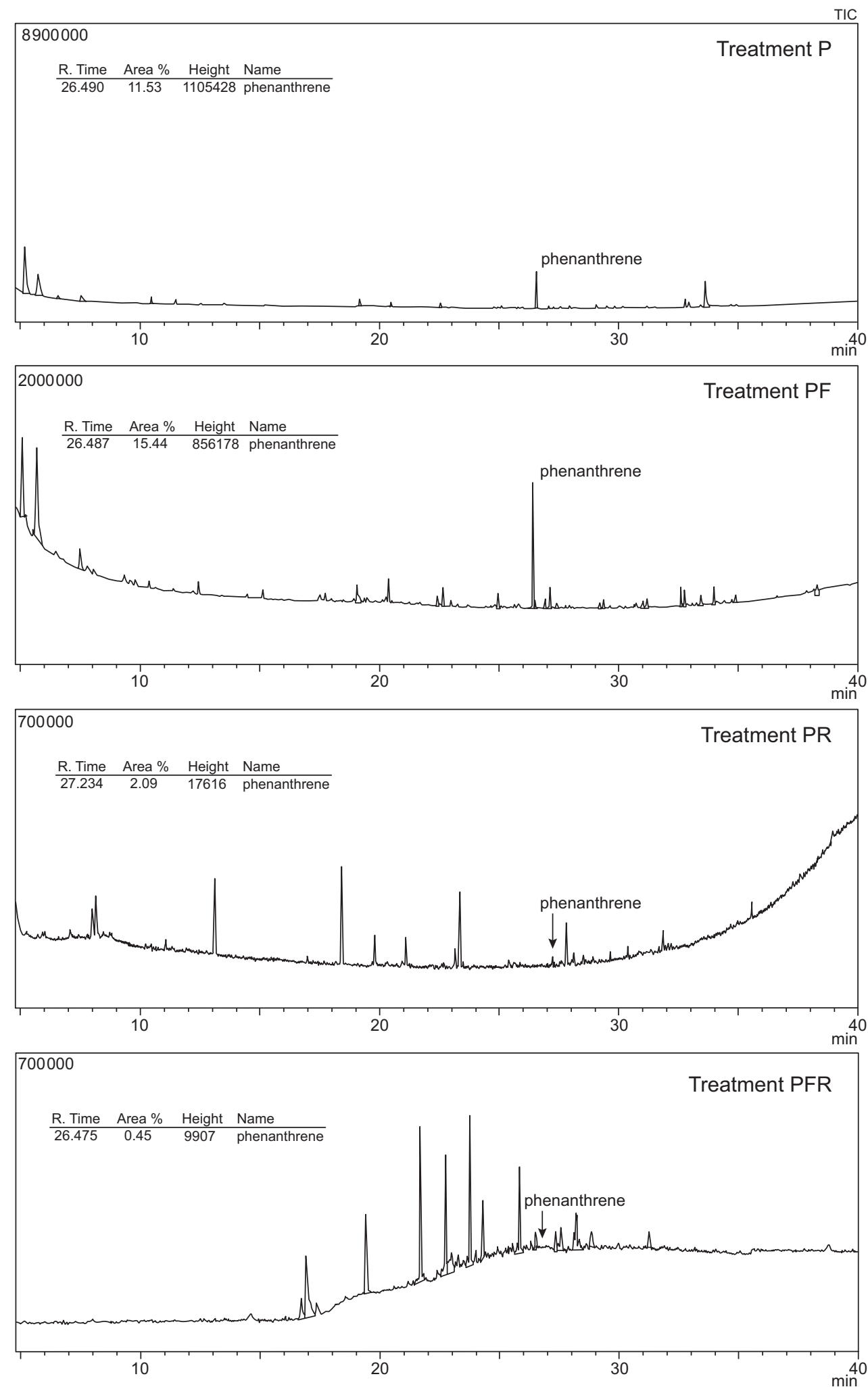

Fig. 4. Total ion chromatogram (TIC) from the gas chromatography-mass spectrometer analysis of phenanthrene spiked soils at the end of the experimental period. Treatments: $\mathrm{P}=$ phenanthrene spiked soil; $\mathrm{PF}=\mathrm{P}$ with fertigation; $\mathrm{PR}=\mathrm{P}$ with ryegrass; $\mathrm{PRF}=\mathrm{P}$ with ryegrass and fertigation 


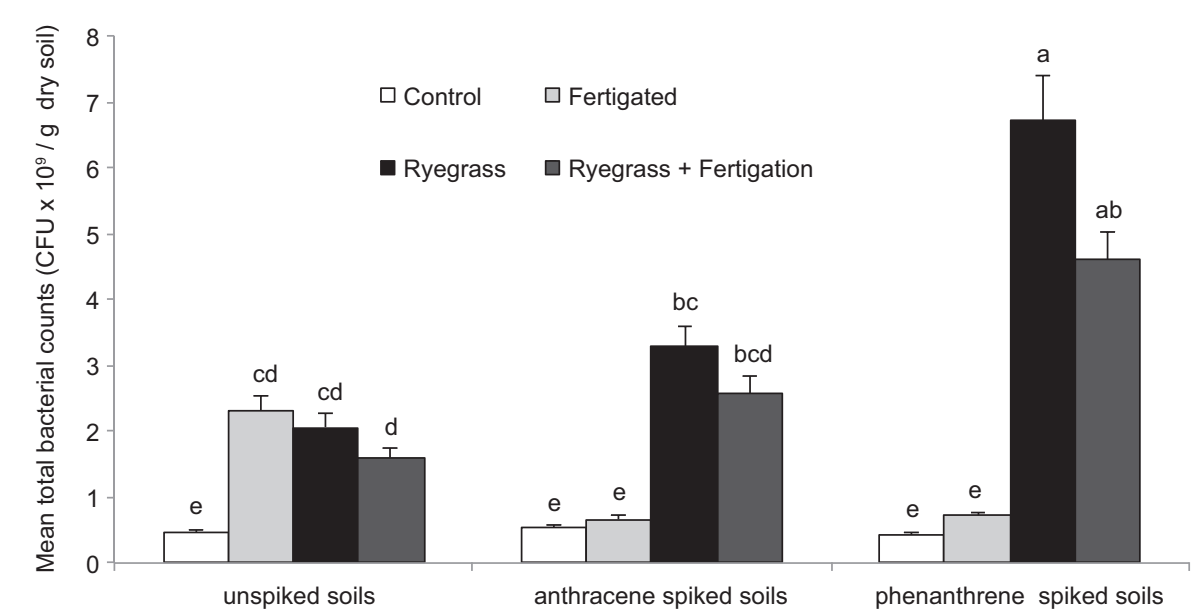

Fig. 5. Mean total bacterial counts $\left(\times 10^{9} \mathrm{CFU} / \mathrm{g}\right)$ at the end of the experimental period. Distinctive groups are marked with different letters $(\mathrm{p}<0.05)$

despite the high spiking-dose used. Growth promoting effects of PAHs were first described by Gräf and Nowak (1966). Low levels (below $10 \mathrm{mg} / \mathrm{kg}$ ) of soil PAHs concentrations were reported to stimulate rather than inhibit plants growth at the early stages of plant development (Maliszewska-Kordybach and Smreczak 2000). Other studies reported that higher phenanthrene levels $(200 \mathrm{mg} / \mathrm{kg})$ produced no significant differences in ryegrass biomass (DW) before 60 days of seedling emergence (Xu et al. 2006, Liu et al. 2013) although, afterwards, a restrain in growth due to toxicity stress was observed, which resulted in a significantly lower biomass than control at the end of the experiment (Liu et al. 2013). Similarly, Binet et al. (2000) reported that shoot and root biomass were significantly lower than control in a 40 days pot experiment using $200 \mathrm{mg} / \mathrm{kg}$ anthracene and phenanthrene spiked soil. But Fismes et al. (2002) observed no detrimental effect on plant growth in soil PAHs concentrations even up to $2526 \mathrm{mg} / \mathrm{kg}$. But herein, a statistically higher production of aerial biomass as the result of soil addition of anthracene or phenanthrene compared to unfertilized control was observed (Table III). An explanation to this may be a positive priming effect (PE) originated as a consequence of anthracene and phenanthrene soil inputs, which released bioavailable nutrients to the soil solution (Joner et al. 2002). This positive PE was reported to decrease in high nutrient availability conditions, as microorganisms may fulfill their nutrient demand by utilizing the added nutrients rather than mineralizing them from native SOM (Dimassi et al. 2014, Liu et al. 2017). Therefore, the PE, which may have occurred in non-fertilized pots, would have masked a fertigation effect on L. perenne biomass and, as a result of this, no significant increase in aerial biomass was observed in fertilized compared to non-fertilized plant treatments.

Alternatively, a rapid initial mineralization of both contaminants cannot be ruled out. Numerous studies have shown that the availability, and therefore, the biodegradation of anthracene and phenanthrene in spiked soils is related to the degree of sorption onto soil organic matter (SOM) (Ahmad et al. 2001, Ahangar et al. 2008), for sorbed substrates are more resistant to biodegradation than non-sorbed ones (Wszolek and Alexander 1979). Soils' capacity to absorb PAHs is positively related to the aromatic constituents of SOM (Ahmad et al. 2001). In the Pampas region, the SOM of coarse textured soils is more aliphatic, less aromatic and less rich in carboxylic acid groups compared to that of fine-textured soils (Galantini et al. 2004). In line with this, anthracene or phenanthrene may have been weakly adsorbed onto the SOM of the typic Hapludoll (Ran et al. 2007), and, therefore, potentially available for microbial degradation.

Both PAHs concentration in root-free soils significantly decreased at the end of the experiment compared to initial concentrations. Previous studies have shown that the number of PAHs-degrading microorganisms and their proportion in the heterotrophic community increased upon previous exposure of soils at PAHs concentrations greater than background (van der Meer et al. 1992). But the pristine soil used in this study was not previously exposed to PAHs pollution. In fact, the Pampas is recognized as a non-polluted region (Torri 2014), 
with very low background concentration levels of PAHs, in the range of $1.8-34 \mathrm{ng} / \mathrm{g}$ (Wilcke et al. 2014). Conversely, other authors indicated that soil autochthonous microbial communities can rapidly degrade low molecular weight PAHs because these ubiquitous compounds are known to be present in all soils at very low concentrations (Stroud et al. 2007). The dissipation of anthracene or phenanthrene in root-free spiked soils at the end of the experiment revealed the catabolic capability of the autochthonous soil microbiota. These results are in good agreement with a previous experiment with the same root-free treatments, where we measured the production of $\mathrm{C}-\mathrm{CO}_{2}$ along 60 days as an indirect estimation of microbial activity (Torri et al. 2018). The production of $\mathrm{C}-\mathrm{CO}_{2}$ in all incubated soils increased from day 0 to day 10 , with no significant differences between treatments. But from day 10 onwards, the average respiration in unspiked soils decreased to a minimum on day 24, whereas $\mathrm{C}-\mathrm{CO}_{2}$ emission in anthracene or phenanthrene spiked soils was significantly higher than controls $(\mathrm{p}<0.01)$, with a maximum between days 10-18, related to PAHs degradation. Apparently, a compatible microflora existed or rapidly established in the Hapludoll soil, which resulted in anthracene or phenanthrene degradation. Therefore, we cannot determine whether PAH degradation in the pristine Hapludoll is a characteristic of indigenous soil microbial communities or an acquired ability induced by exposure to undetectable levels of PAHs. In any case, $77.3 \%$ of anthracene and $91.2 \%$ of phenanthrene were removed from the unplanted spiked soils at the end of the experimental period. Similar results for spiked soils were reported by Binet et al. (2000), $\mathrm{Xu}$ et al. (2006) and Cennerazzo et al. (2017) in pot experiments. Nonetheless, the results obtained in this study may differ from those obtained in field conditions, because organic compounds that have aged in contaminated soils are less bioavailable than in freshly spiked soils and therefore, their removal rate may be reported to occur relatively slow (Fu et al. 2012). Besides, adverse environmental conditions in natural soils in comparison with laboratory conditions usually cause less efficient biodegradation of organic pollutants.

As expected, L. perenne favored to decrease the concentration of anthracene and phenanthrene in spiked soils compared to non-vegetated spiked soils (Table III). The removal of PAHs from vegetated soils may occur by three processes: abiotic dissipation, plant uptake or degradation by soil microorganisms. In this pot experiment, abiotic dissipation (leaching or volatilization) was prevented by the experimental conditions chosen. On the other hand, plant uptake of phenanthrene or anthracene has been reported to be very low in many phytoremediation studies. Reilley et al. (1994) found that total accumulation of anthracene in roots and shoots of different plant species accounted for less than $0.03 \%$ of total added compound, Cheema et al. (2010) indicated that only $1.1 \%$ of the spiked phenanthrene was absorbed by $L$. perenne roots after a 65 days pot trial, while Cennerazzo et al. (2017) reported that less than $1 \%$ of total phenanthrene carbon was taken up by ryegrass roots after 21 days. Similar results were reported by Fu et al. (2012). An explanation to this is the low water solubility of PAHs (Binet et al. 2000), together with the non-polar organic composition of root tissue, such as lipid contents (Chiou et al. 2001, Gao and Zhu 2004) that might prevent significant uptake by plant roots. In the light of this, biodegradation by native soil microorganisms is likely to be the dominant mechanism for the dissipation of anthracene and phenanthrene in the rhizosphere of L. perenne treatments. Some researchers speculated that plants may respond to the presence of a chemical stress in soil by increasing or changing exudation, modifying rhizospheric microflora composition or activity (Walton et al. 1994). The synergistic effect of bacteria and root exudates on the selective growth of PAHs degraders in contaminated soils has been previously reported (Khan et al. 2013, Yang et al. 2014, Guo et al. 2017). In addition, roots possess wall-bound and soluble oxidative enzymes that may be directly implicated in the degradation of PAHs (Rezek et al. 2008). These results are consistent with the findings of previous studies, which showed that anthracene and phenanthrene degradation in spiked soil was significantly higher in rhizospheric than in non-rhizospheric soils (Günther et al. 1996, Binet et al. 2000, Korade and Fulekar 2009).

Soil removal of phenanthrene and anthracene was different, although they both contain three fused aromatic rings. In all cases, the degradation of phenanthrene was significantly higher than anthracene (Table III). This result may be related to the higher water solubility of phenanthrene $(1.1 \mathrm{mg} / \mathrm{L})$, as compared with anthracene $(0.045 \mathrm{mg} / \mathrm{L})$ (Bianche et al. 2014). Many microorganisms are known to degrade PAHs only when they are dissolved in an aqueous media (Johnsen et al. 2005). In fact, water solubility of many PAHs is the rate-limiting factor for biodegradation since microbial biodegradation is considerably slower from sorbed sites than from the soil solution (Gordon and Millero 1985, Semple et al. 2003). Therefore, a large labile pool of 
phenanthrene may have been present in the soil solution of the spiked typic Hapludoll, readily available for soil microorganisms' degradation. This process lead, in turn, to the desorption of more phenanthrene from the solid phase to the aqueous phase (Mueller and Shann 2006), increasing phenanthrene degradation respect to anthracene degradation.

The addition of inorganic nutrients is a strategy to enhance PAHs microbial biodegradation rate in contaminated soils (Kalantary et al. 2014). But this was not the case here. Contrary to what we expected, no significant differences in anthracene or phenanthrene dissipation were observed between fertilized and nonfertilized treatments. Soils in the Pampas region are moderately acid, low in available $\mathrm{P}$, and have high organic carbon content (Torri and Lavado 2002). Therefore, nutrient availability seemed to be adequate in non-fertilized treatments along the studied period, for no significant differences in terms of anthracene or phenanthrene degradation were observed between fertilized and non-fertilized treatments at the end of the experimental period.

Soil microbial biomass is closely related to soil fertility (Zhong and Cai, 2007). Total bacterial counts in the unspiked soil was similar to other soils of the Pampas region (Merini et al. 2007). Although the effects of nutrients on microbial biomass have been investigated intensively, the results are inconsistent. Some studies showed that chemical fertilizers increased microbial biomass (Geisseler and Scow 2014), but other researchers reported that soil $P$ and $\mathrm{N}$ contents had no significant effects on soil microbial populations (Zhong and Cai 2007). Some other evidence suggests the use of nitrogen fertilizers may cause ammonia or nitrite toxicity to microorganisms (Tibbett et al. 2011), which may be particularly severe in sandy soils with limited buffering and water holding capacity (Ferguson et al. 2003). In our study, the chemical fertigation (NPK) of the pristine soil improved nutrient availability, increasing total bacteria counts as compared to the control at the end of the experimental period.

As expected, the growth of $L$. perenne promoted the degradation of anthracene and phenanthrene, and total bacterial counts were significantly stimulated. The bacterial abundances in rhizosphere soils were higher than those in root-free soils, indicating that $L$. perenne roots significantly stimulated the growth of the bacteria in spiked soils. At the end of the experiment, the highest value of total bacteria counts was observed in phenanthrene spiked soils with plant treatment (PR). This treatment exhibited the highest removal efficiency $(99.7 \%)$. The increase of bacterial counts in the rhizosphere has already been observed in other studies (Shahsavari et al. 2015, Thomas and Cébron 2016, Guo et al. 2017). Although the growth of hydrocarbon-degrading bacteria may be strongly enhanced by fertigation with inorganic $\mathrm{N}$ and $\mathrm{P}$ (Nikolopoulou and Kalogerakis 2010), this was not observed here. These results suggest that nutrient availability was adequate in non-fertilized spiked soils, or ammonia or nitrite toxicity to microorganisms as a result of $\mathrm{N}$ addition, as indicated above. Nonetheless, further investigation is needed to identify the microbial communities responsible for anthracene and phenanthrene dissipation in this pristine soil.

\section{CONCLUSIONS}

The major finding of the present study was the natural capacity of a pristine soil of the Pampas region, which was not previously exposed to PAH pollution, to degrade anthracene or phenanthrene. No phytotoxic effects of both contaminants on $L$. perenne growth were observed; on the contrary, plant aboveground biomass significantly increased as a result of treatments. On the other hand, ryegrass significantly enhanced soil dissipation of both contaminants. The addition of inorganic nutrients did not produce a biostimulation effect. In all cases, the dissipation of phenanthrene was significantly higher than anthracene, and may be related to the higher water solubility of the former.

Results suggest that microbial degradation was largely responsible for PAHs dissipation, suggesting that indigenous PAHs degrading microorganisms might exist in the pristine Hapludoll of the Pampas region, and exert a degrading function. At the end of the experimental period, total bacteria counts in rhizosphere soils were higher than those in nonrhizosphere soils, revealing that L. perenne's roots significantly stimulated the growth of bacteria in spiked soil.

Nevertheless, freshly applied PAHs may not behave in the same way as aged pollutants in contaminated soils. Moreover, the rate of PAHs biodegradation in natural environments may be different compared to those observed in this experiment. This is because environmental factors, which determine the success of bioremediation, may not be maintained at optimal range in contaminated environments. Provision of oxygen, moisture, nutrient availability, $\mathrm{pH}$ and temperature are amongst the most important environmental factors that need to be kept at optimal range for autochthonous (indigenous) microorganisms' 
growth and metabolism, and for plant survival and growth. The present findings are based on a pot experiment. Therefore, this remediation strategy needs to be applied and validated in the field, to ensure the safe and cost-effective restoration of PAHs contaminated soils.

\section{REFERENCES}

Acosta-Santoyo G., Cameselle C. and Bustos E. (2017). Electrokinetic - Enhanced ryegrass cultures in soils polluted with organic and inorganic compounds. Environ. Res. 158, 118-125. https://doi.org/10.1016/j. envres.2017.06.004

Ahangar A.G., Smernik R.J., Kookana R.S. and Chittleborough D.J. (2008). Separating the effects of organic matter-mineral interactions and organic matter chemistry on the sorption of diuron and phenanthrene. Chemosphere 72 (6), 886-890. https://doi.org/10.1016/j. chemosphere.2008.03.059

Ahmad R., Kookana R.S., Alston A.M. and Bromilow R.H. (2001). Differences in sorption behaviour of carbaryl and phosalone in soils from Australia, Pakistan, and the United Kingdom. Environ. Sci.Technol. 39 (4), 893-908. https://doi.org/10.1071/SR00021

Alvaro C. E. S., Arocena L. A., Martínez M. Á. and Nudelman N.E.S. (2017). Biodegradación aerobia de fracciones de hidrocarburos provenientes de la actividad petrolera en un suelo de la región patagonia norte, Argentina. Rev. Int. Contam. Ambie. 33 (2), 247-257. https://doi.org/10.20937/rica.2017.33.02.06

Anyanwu I.N. and Semple K.T. (2015). Phytotoxicity of phenanthrene and its nitrogen polycyclic aromatic hydrocarbon analogues in ageing soil. Water Air Soil Pollut. 226 (10), 347. https://doi.org/10.1007/s11270015-2589-x

Baruah R., Mishra S.K., Kalita D.J., Silla Y., Chauhan P.S., Singh A.K. and Deka-Boruah H.P. (2017). Assessment of bacterial diversity associated with crude oil-contaminated soil samples from Assam. Int. J. Environ. Sci. Technol. 14 (10), 2155-2172. https://doi. org/10.1007/s13762-017-1294-2

Biache C., Mansuy-Huault L. and Faure P. (2014). Impact of oxidation and biodegradation on the most commonly used polycyclic aromatic hydrocarbon (PAH) diagnostic ratios: Implications for the source identifications. J. Haz. Mat. 267, 31-39. https://doi.org/10.1016/j. jhazmat.2013.12.036

Binet P., Portal J.M. and Leyval C. (2000). Dissipation of 3-6-ring polycyclic aromatic hydrocarbons in the rhizosphere of ryegrass. Soil Biol. Biochem. 32 (14), 20112017. https://doi.org/10.1016/s0038-0717(00)00100-0
Bouchez M., Blanchet D. and Vandercastelle J.P. (1995). Degradation of polycyclic aromatic hydrocarbons by pure strains and by defined strain associations: inhibition phenomena and cometabolism. Appl. Microbiol. Biotechnol. 43 (1), 156-164. https://doi.org/10.1007/ BF00170638

Bourceret A., Leyval C., de Fouquet C. and Cébron A. (2015). Mapping the centimeter-scale spatial variability of PAHs and microbial populations in the rhizosphere of two plants. PLoS ONE 10 (11), e0142851. https://doi.org/10.1371/journal.pone.0142851

Cennerazzo J., de Junet A., Audinot J-N. and Leyval C. (2017). Dynamics of PAHs and derived organic compounds in a soil-plant mesocosm spiked with ${ }^{13} \mathrm{C}$ phenanthrene. Chemosphere 168, 1619-1627. https:// doi.org/10.1016/j.chemosphere.2016.11.145

Cheema S.A., Khan M.I., Shen C., Tanga X., Farooq M., Chen L., Zhang C. and Chen Y. (2010). Degradation of phenanthrene and pyrene in spiked soils by single and combined plants cultivation. J. Haz. Mat. 177 (1-3), 384-389. https://doi.org/10.1016/j. jhazmat.2009.12.044

Cheung K.C., Zhang J.Y., Deng H.H., Ou Y.K., Leung H.M., Wu S.C. and Wong M.H. (2008). Interaction of higher plant (jute), electrofused bacteria and mycorrhiza on anthracene biodegradation. Bioresource Technol. 99 (7), 2148-2155. https://doi.org/10.1016/j. biortech.2007.05.037

Chiapusio G., Pujol S., Toussaint M.L., Badot P.M. and Binet P. (2007). Phenanthrene toxicity and dissipation in rhizosphere of grassland plants (Lolium perenne $\mathrm{L}$. and Trifolium pratense L.) in three spiked soils. Plant Soil. 294 (1-2), 103-112. https://doi.org/10.1007/ s11104-007-9234-4

Chiou C.T., Sheng G. and Manes M. (2001). A partitionlimited model for the plant uptake of organic contaminants from soil and water. Environ. Sci. Technol. 35 (7), 1437-1444. https://doi.org/10.1021/es0017561

Chirakkara A. and Reddy K.R. (2015). Biomass and chemical amendments for enhanced phytoremediation of mixed contaminated soils. Ecol. Eng. 85, 265-274. https://doi.org/10.1016/j.ecoleng.2015.09.029

Chouychai W., Thongkukiatkul A., Upatham S., Lee H., Pokethitiyook P. and Kruatrachue M. (2007). Phytotoxicity assay of crop plants to phenanthrene and pyrene contaminants in acidic soil. Environ. Toxicol. 22 (6), 597-604. https://doi.org/10.1002/tox.20285

Couto M.N.P.F.S., Monteiro E. and Vasconcelos M.T.S.D. (2010). Mesocosm trials of bioremediation of contaminated soil of a petroleum refinery: Comparison of natural attenuation, biostimulation and bioaugmentation. Environ. Sci. Pollut. Res. 17 (7), 1339-1346. https:// doi.org/10.1007/s11356-010-0318-y 
Delille D., Coulon F. and Pelletier E. (2004). Biostimulation of natural microbial assemblage in oil-amended vegetated and desert sub-Antarctic soils. Microb. Ecol. 47 (4), 407-415. https://doi.org/10.1007/s00248-0032024-5

Díaz-Zorita M., Buschiazzo D.E. and Peineman N. (1999). Soil organic matter and wheat productivity in the Semiarid Argentine Pampas. Agron. J. 91, 276-279. https://doi.org/10.2134/agronj1999.0002196200910 0020016x

Díaz-Zorita M. and Buschiazzo D.E. (2006). Soils of the Pampas. In: Encyclopedia of soil science (R. Lal, Ed). Marcel Dekker, Inc. New York, USA, pp. 1653-1657. https://doi.org/10.1081/E-ESS-120024794

Dimassi B., Mary B., Fontaine S., Perveen N., Revaillot S. and Cohan J.P. (2014). Effect of nutrients availability and long-term tillage on priming effect and soil $\mathrm{C} \mathrm{min-}$ eralization. Soil. Biol. Biochem. 78, 332-339. https:// doi.org/10.1016/j.soilbio.2014.07.016

Doick K.J., Lee P.H. and Semple K.T. (2003). Assessment of spiking procedures for the introduction of a phenanthrene-LNAPL mixture into field-wet soil. Environ. Pollut. 126 (3), 399-406. https://doi.org/10.1016/ S0269-7491(03)00230-6

Duan Y., Shen G., Tao S., Hong J., Chen Y., Xue M., Li T., Su S., Shen H., Fu X., Meng Q., Zhang J., Zhang B., Hana X. and Song K. (2015). Characteristics of polycyclic aromatic hydrocarbons in agricultural soils of a typical coke production base in Shanxi, China. Chemosphere 127, 64-69. https://doi.org/10.1016/j. chemosphere.2014.12.075

Dubrovskaya E.V., Pozdnyakova N.N., Muratova A.Y. and Turkovskaya O.V. (2016). Changes in phytotoxicity of polycyclic aromatic hydrocarbons in the course of microbial degradation. Russ. J. Plant Physl. 63 (1), 172-179. https://doi.org/10.1134/S1021443716010052

Dzantor E.K., Chekol T. and Vough L.R. (2000). Feasibility of using forage grasses and legumes for phytoremediation of organic pollutants. J. Environ. Sci. Heal. A. 35 (9), 1645-1661. https://doi. org/10.1080/10934520009377061

EC (2001). Ambient air pollution by polycyclic aromatic hydrocarbons (PAH). Position paper. Official publications of the European Communities. European Commission. Luxembourg, Luxembourg, 70 pp.

Eom I.C., Rast C., Veber A.M. and Vasseur P. (2007). Ecotoxicity of a polycyclic aromatic hydrocarbon (PAH)- contaminated soil. Ecotoxicol. Environ. Saf. 67, 190-205. https://doi.org/10.1016/j. ecoenv.2006.12.020

Fawole M.O. and Oso B.A. (2007). Laboratory manual of microbiology. Spectrum Books Limited, Ibadan, Nigeria, 1988 pp.
Ferguson S.H., Woinarski A.Z., Snape I., Morris C.E. and Revill A.T. (2004). A field trial of in situ chemical oxidation to remediate long-term diesel contaminated Antarctic soil. Cold. Reg. Sci. Technol. 40 (1-2), 4760. https://doi.org/10.1016/j.coldregions.2004.05.008

Fernández-Luqueño F., López-Valdez F., Pérez-Morales C., García-Mayagoitia S., Sarabia-Castillo C. R., Sarabia-Castillo C.R. and Pérez-Ríos S.R. (2017). Enhancing decontamination of PAHs-polluted soils: Role of organic and mineral amendments. In: Enhancing cleanup of environmental pollutants (N. A. Anjum, S. Singh Gill and N. Tuteja, Eds.). Springer International, Cham, Switzerland, pp. 339-368. https:// doi.org/10.1007/978-3-319-55423-5

Fismes J., Perrin-Ganier C., Empereur-Bissonnet P. and Morel J.L. (2002). Soil-to-root transfer and translocation of polycyclic aromatic hydrocarbons by vegetables grown on industrial contaminated soils. J. Environ. Qual. 31 (5), 1649-1656. https://doi.org/10.2134/jeq2002.1649

Fu D., Teng Y., Shen Y., Sun M., Tu C., Luo Y., Li Z. and Christie P. (2012). Dissipation of polycyclic aromatic hydrocarbons and microbial activity in a field soil planted with perennial ryegrass. Front. Environ. Sci. Eng. 6 (3), 330-335. https://doi.org/10.1007/s11783011-0366-7

Galantini J.A., Senesi N., Brunetti G. and Rosell R. (2004). Influence of texture on organic matter distribution and quality and nitrogen and sulphur status in semiarid Pampean grassland soils of Argentina. Geoderma 123 (1), 143-152. https://doi.org/10.1016/j. geoderma.2004.02.008

Gao Y. and Zhu L. (2004). Plant uptake, accumulation and translocation of phenanthrene and pyrene in soils. Chemosphere 55 (9), 1169-1178. https://doi.org/10.1016/j. chemosphere.2004.01.037

Gavrilescu M. (2005). Fate of pesticides in the environment and its bioremediation. Eng. Life Sc. 5 (6), 497526. https://doi.org/10.1002/elsc.200520098

Geisseler D. and Scow K.M. (2014). Long-term effects of mineral fertilizers on soil microorganisms-A review. Soil Biol. Biochem. 75, 54-63. https://doi. org/10.1016/j.soilbio.2014.03.023

Gordon A.S. and Millero F.J. (1985). Adsorption mediated decrease in the biodegradation rate of organic compounds. Microbial. Ecol. 11 (4), 289-298. https:// doi.org/10.1007/BF02016813

Gräf W. and Nowak W. (1966). Promotion of growth in lower and higher plants by carcinogenic polycyclic aromatics. Arch. Hyg. Bakteriol. 150 (6), 513-528.

Günther T., Dornberger U. and Fritsche W. (1996). Effects of ryegrass on biodegradation of hydrocarbons in soil. Chemosphere 33 (2), 203-215. https://doi. org/10.1016/0045-6535(96)00164-6 
Guo M., Gong Z., Miao R., Rookes J., Cahill D. and Zhuang J. (2017). Microbial mechanisms controlling the rhizosphere effect of ryegrass on degradation of polycyclic aromatic hydrocarbons in an aged-contaminated agricultural soil. Soil Biol. Biochem. 113, 130-142. https://doi.org/10.1016/j.soilbio.2017.06.006

Hakanson L. (1984). Sediment sampling in different aquatic environments: statistical aspects. Water Resour. Res. 20 (1), 41-46. https://doi.org/10.1029/ WR020i001p00041

Han X., Hu H., Shi X., Zhang L. and He J. (2017). Effects of different agricultural wastes on the dissipation of PAHs and the PAH-degrading genes in a PAH-contaminated soil. Chemosphere 172, 286-293. https:// doi.org/10.1016/j.chemosphere.2017.01.012

Huang X., Alawi Y.E., Penrose D.M., Glick B.R. and Greenberg B.M. (2004). A multi-process phytoremediation system for removal of polycyclic aromatic hydrocarbons from contaminated soils. Environ. Pollut. 130 (3), 465476. https://doi.org/10.1016/j.envpol.2003.09.031

Johnsen A., Wick L. and Harms H. (2005). Principles of microbial PAH-degradation in soil. Environ. Pollut. 133 (1), 71-84. https://doi.org/10.1016/j.envpol.2004.04.015

Joner E.J., Corgi S.C., Amellal N. and Leyval C. (2002). Nutritional constraints to degradation of polycyclic aromatic hydrocarbons in a simulated rhizosphere. Soil Biol. Biochem. 34 (6), 859-64. https://doi.org/10.1016/ s0038-0717(02)00018-4

Kalantary R.R., Mohseni-Bandpi A., Esrafili A., Nasseri S., Ashmagh F.R., Jorfi S. and Ja'fari M. (2014). Effectiveness of biostimulation through nutrient content on the bioremediation of phenanthrene contaminated soil. J. Environ. Health. Sci. 12 (1), 143. https://doi. org/10.1186/s40201-014-0143-1

Kanaly R.A. and Harayama S. (2000). Biodegradation of high-molecular weight polycyclic aromatic hydrocarbons by bacteria. J. Bacteriol. 182 (8), 2059-2067. https://doi.org/10.1128/JB.182.8.2059-2067.2000

Keith L. H. (2014). The Source of U.S. EPA's Sixteen PAH Priority Pollutants. Polycycl. Aromat. Comp. 35 (2-4), 147-160. https://doi.org/10.1080/10406638 .2014 .892886

Khan S., Afzal M., Iqbal S. and Khan Q.M. (2013). Plant-bacteria partnerships for the remediation of hydrocarbon contaminated soils. Chemosphere 90 (4), 1317-1332. https://doi.org/10.1016/j.chemosphere.2012.09.045

Kong L., Gao Y., Zhou Q., Zhao X. and Sun Z. (2018). Biochar accelerates PAHs biodegradation in petroleum-polluted soil by biostimulation strategy. J. Hazard. Mater. 343, 276-284 https://doi.org/10.1016/j. jhazmat.2017.09.040
Korade D.L. and Fulekar M.H. (2009). Effect of organic contaminants on seed germination of Lolium multiflorum in soil. Bio. Med. 1 (1), 28-34.

Li F., Zeng X., Yang J., Khou K., Zan Q., Lei A. and Tam N.F. (2014). Contamination of polycyclic aromatic hydrocarbons (PAHs) in surface sediments and plants mangrove swamps in Shenzhen, China. Mar Pollut. Bull. 85 (2), 590-596.

Liu S.L., Cao Z.H. and Liu H.E. (2013). Effect of ryegrass (Lolium multiflorum L.) growth on degradation of phenanthrene and enzyme activity in soil. Plant Soil Environ. 59 (6), 247-253.

Liu X-J.A., Sun J., Mau R.L., Finley B.K., Compson Z.G., van Gestel N., Brown J.R., Schwartz E., Dijkstra P. and Hungate B.A. (2017). Labile carbon input determines the direction and magnitude of the priming effect. Appl. Soil Ecol. 109, 7-13. https://doi.org/10.1016/j. apsoil.2016.10.002

Ma B., He Y., Chen H., Xu J-m. and Rengel Z. (2010). Dissipation of polycyclic aromatic hydrocarbons (PAHs) in the rhizosphere: synthesis through metaanalysis. Environ. Pollut. 158 (3), 855-861. https:// doi.org/10.1016/j.envpol.2009.09.024

MacNaughton S.J., Siephen J.R., Venosa A.D., Davis G.A., Chang Y.J. and White D.C. (1999). Microbial population changes during bioremediation of an experimental oil spill. Appl. Environ. Microbiol. 65 (8), 3566-3574

Maliszewska-Kordybach B. and Smreczak B. (2000). Ecotoxicological activity of soils polluted with polycyclic aromatic hydrocarbons (PAHs) - effect on plants. Environ. Technol. 21 (10), 1099-1110. https://doi.org /10.1080/09593330.2000.9618996

Mallakin A., Babu T.S., Dixon D.G. and Greenberg B.M. (2002). Sites of toxicity of specific photooxidation products of anthracene to higher plants: inhibition of photosynthetic activity and electron transport in Lemna gibba L. G-3 (duckweed). Environ. Toxicol. 17 (5), 462-71. https://doi.org/10.1002/tox.10080

Margesin R. and Schinner F. (2001). Bioremediation (natural attenuation and biostimulation) of diesel-oilcontaminated soil in an Alpine glacier skiing area. Appl. Environ. Microbiol. 67 (7), 3127- 3133. https:// doi.org/10.1128/aem.67.7.3127-3133.2001

Martin B.C., George S.J., Price C.A., Ryan M.H. and Tibbett M. (2014). The role of root exuded low molecular weight organic anions in facilitating petroleum hydrocarbon degradation: current knowledge and future directions. Sci. Total Environ. 472, 642-653. https:// doi.org/10.1016/j.scitotenv.2013.11.050

Merini L.J., Cuadrado V., Flocco C.G. and Giulietti A.M. (2007). Dissipation of 2,4-D in soils of the Humid Pampa region, Argentina: A microcosm study. 
Chemosphere 68 (2), 259-265 https://doi.org/10.1016/j. chemosphere.2007.01.012

Mizuno I., Arrigo N.M. and Svartz H. (1978). Método rápido de determinación de humedad equivalente. Memorias VIII Reunión Argentina de la Ciencia del Suelo. Buenos Aires, Argentina. 25 al 30 de septiembre de 1978. Libro de Actas, pp. 59-63.

Mueller K.E. and Shann J.R. (2006). PAH dissipation in spiked soil: impacts of bioavailability, microbial activity, and trees. Chemosphere. 64 (6), 1006-1014. https:// doi.org/10.1016/j.chemosphere.2005.12.051

Nakata C., Qualizza C., MacKinnon M. and Renault S. (2011). Growth and physiological responses of Triticum aestivum and Deschampsia caespitosa exposed to petroleum coke. Water Air Soil Poll. 216 (1-4), 59-72. https://doi.org/10.1007/s11270-010-0514-x

Nandal M., Solanki P., Rastogi M. and Hooda R. (2015). Bioremediation: a sustainable tool for environmental management of oily sludge. Nat. Env. Poll. Tech. 14 (1), 181-190.

Nikolopoulou M. and Kalogerakis N. (2010). Biostimulation strategies for enhanced bioremediation of marine oil spills including chronic pollution. In: Handbook of hydrocarbon and lipid microbiology (K.N. Timmis, Ed.). Springer, Berlin, Heidelberg, Germany, pp. 2521-2529. https://doi.org/10.1007/978-3-31944535-9_7-1

Nikolopoulou M., Pasadakis N. and Kalogerakis N. (2013). Evaluation of autochthonous bioaugmentation and biostimulation during microcosm-simulated oil spills. Mar. Pollut. Bull., 72 (1), 165-173. https://doi. org/10.1016/j.marpolbul.2013.04.007

Northcott G.L. and Jones K.C. (2000). Developing a standard spiking procedure for the introduction of hydrophobic organic compounds into field-wet soil. Environ. Toxicol. Chem. 19 (10), 2409-2417. https:// doi.org/10.1002/etc.5620191004

Noy-Meir I. (1973). Desert ecosystems: environment and producers. Annu. Rev. Ecol. Evol. Syst. 4, 25-52.

Olson P.E, Wong T., Leigh M.B. and Fletcher J.S. (2003). Allometric modeling of plant root growth and its application in rhizosphere remediation of soil contaminants. Environ. Sci. Technol. 37 (3), 638-643. https://doi. org/10.1021/es026099m

PROSAP/EPSA (2010). Resolución del Ministerio de Asuntos Agrarios N ${ }^{\circ} 84 / 10.2010$. Programa de Servicios Agrícolas Provinciales, Estrategia Provincial para el Sector Agroalimentario. [online]. http://www.prosap.gov.ar/webDocs/EPSA_BuenAs.pdf 18/10/2019

Ran Y., Sun K., Yang Y., Xing B.S. and Zeng E. (2007). Strong sorption of phenanthrene by condensed organic matter in soils and sediments. Environ. Sci. Technol. 41 (11), 3952-3958. https://doi.org/10.1021/es062928i
Reilley K.A., Banks M. K. and Schwab A.P. (1996). Dissipation of polycyclic aromatic hydrocarbons in the rhizosphere. J. Environ. Qual. 25 (2), 212. https://doi. org/10.2134/jeq1996.00472425002500020002x

Rezek J., in der Wiesche C., Macková M., Zadrazil F. and Macek T. (2008). The effect of ryegrass (Lolium perenne) on decrease of $\mathrm{PAH}$ content in long term contaminated soil. Chemosphere. 70 (9), 1603-1608. https://doi.org/10.1016/j.chemosphere.2007.08.003

Ruberto L.A.M., Vazquez S.C., Curtosi A., Mestre M.C., Pelletier E. and Mac Cormack W.P. (2006). Phenanthrene biodegradation in soils using an Antarctic bacterial consortium. Bioremediat. J. 10 (4), 191-201. https://doi.org/10.1080/10889860601021449

Sabaté J., Viñas M. and Solanas A.M. (2004). Laboratoryscale bioremediation experiments on hydrocarboncontaminated soils. Int. Biodeter. Biodegr. 54 (1), 19-25. https://doi.org/10.1016/j.ibiod.2003.12.002

Salanitro J. P., Dorn P.B., Huesemann M.H., Moore K.O., Rhodes, I.A., Rice Jackson, L. M., Vipond T.E., Western M.M. and Wisniewski H.L. (1997). Crude oil hydrocarbon bioremediation and soil Ecotoxicity Assessment. Environ. Sci. Technol, 31 (6), 1769-1776. https://doi.org/10.1021/es960793i

Semple K.T., Morris A.W. and Paton J.I. (2003). Bioavailabilityof hydrophobic organic contaminants in soils: fundamental concepts and techniques for analysis. Eur. J. Soil Sci. 54 (4), 809-818. https://doi. org/10.1046/j.1351-0754.2003.0564.x

Shahsavari E., Adetutu E.M., Taha M. and Ball A.S. (2015). Rhizoremediation of phenanthrene and pyrene contaminated soil using wheat. J. Environ. Manage. 155, 171-176. https://doi.org/10.1016/j.jenvman.2015.03.027

Silva I.S., Grossman M. and Durranta L.R. (2009). Degradation of polycyclic aromatic hydrocarbons (2-7 rings) under microaerobic and very-low-oxygen conditions by soil fungi. Int. Biodeterior. Biodegrad. 63 (2), 224229. https://doi.org/10.1016/j.ibiod.2008.09.008

Smith M.J., Flowers T.H., Duncan H.J. and Alder J. (2006). Effects of polycyclic aromatic hydrocarbons on germination and subsequent growth of grasses and legumes in freshly contaminated soil and soil with aged PAHs residues. Environ. Pollut. 141 (3), 519-525. https://doi. org/10.1016/j.envpol.2005.08.061

Soleimani M.M., Afyuni M.A., Hajabbasi F., Nourbakhsh M.R. and Sabzalian J.H. (2010). Christensen, Phytoremediation of an aged petroleum contaminated soil using endophyte infected and non-infected grasses. Chemosphere. 81 (9), 1084-1090 https://doi.org/10.1016/j. chemosphere.2010.09.034

Stroud J.L., Paton G.I. and Semple K.T. (2007). Microbealiphatic hydrocarbon interactions in soil; implications 
for biodegradation and bioremediation. J. Appl. Microbiol. 102 (2), 1239-1253. https://doi.org/10.1111/ j.1365-2672.2007.03401.x

Thomas F. and Cebron A. (2016). Short-term rhizosphere effect on available carbon sources, phenanthrene degradation, and active microbiome in an aged contaminated industrial soil. Front Microbiol. 7, 92. https:// doi.org/10.3389/fmicb.2016.00092

Tibbett M., George S.J., Davie A., Barron A., Milton N. and Greenwood P.F. (2011). Just add water and salt: the optimisation of petrogenic hydrocarbon biodegradation in soils from semi-arid Barrow Island, Western Australia. Water Air Soil Pollut. 216 (1-4), 513-525. https://doi.org/10.1007/s11270-010-0549-Z

Torri S. I., Zubillaga M. and Cusato M. (2009). Potential of Discaria americana for metal stabilization on soils amended with biosolids and ash-spiked biosolids. Int. J. Phytoremediat. 11 (2), 187-199. https://doi. org/10.1080/15226510802378475

Torri S., Urricariet A.S. and Lavado R. (2011). Micronutrient availability in crop soils of the Pampas region, Argentina. In: Soil nutrients (M. Miransari, Ed.). Nova Science Publishers, Inc., New York, USA, pp 277-296.

Torri S.I. (2014). Sustainable agriculture in the pampas region, Argentina. In: Sustainability behind sustainability (A. Zorpas, Ed.). Nova Science Publishers, Inc. Hauppauge, USA, pp. 297-318.

Torri S.I. and Alberti C. (2012). Characterization of organic compounds from biosolids of Buenos Aires City. J. Soil Sci. Plant Nutr. 12 (1), 143-152. https:// doi.org/10.4067/S0718-95162012000100012

Torri S.I. and Lavado R.S. (2002). Distribution and availability of potentially toxic elements in representative soils of Buenos Aires province as a result of biosolids application. Ciencia del Suelo 20, 98-109.

Torri S.I., Cabrera M.N. and Alberti C. (2018). Potential respiration during the biostimulation of a soil contaminated with aromatic policyclic hydrocarbons Rev. Int. Contam. Ambie. 34 (1), 127-136. https://doi. org/10.20937/RICA.2018.34.01.11

Torri S.I., Corrêa R.S., Renella G., Perelomov L. and Valdecantos A. (2014). Biosolids soil application: Agronomic and environmental implications 2013. Applied Environ. Soil Sci. (4) article ID: 314730. https:// doi.org/10.1155/2014/314730

Torri S.I., Descalzi C. and Frusso, E. (2009). Estimation of leaf area in pecan cultivars (Carya illinoinensis). Cien. Inv. Agr. 36 (1), 53-58. https://doi.org/10.4067/ S0718-16202009000100004

USEPA (1997). Sampling and analysis procedures for screening of industrial effluents for priority pollutants. United States Environmental Protection Agency. Cincinnati, USA, 69 pp.
Vácha R, Čechmánková J. and Skála J. (2010). Polycyclic aromatic hydrocarbons in soil and selected plants. Plant Soil. Environ. 56 (9), 434-443.

van der Meer J.R., de Vos V.M., Harayama S. and Zehnder A.J. (1992). Molecular mechanisms of genetic adaptation to xenobiotic compounds. Microbiol. Rev. 56 (4), 677-694.

Walton B.T., Hoylman A.M., Perez M.M., Anderson T.A., Johnson T.R., Guthrie E.A. and Christman R.F. (1994). Rhizosphere microbial communities as a plant defense against toxic substances in soils. In: Bioremediation through rhizosphere technology (T.A. Anderson and J.R. Coats, Eds.). American Chemical Society, Washington, USA, pp. 82-92.

Wilcke W., Bandowe B.A.M., Gomez-Lueso M., Ruppenthal M., del-Valle H. and Oelmann Y. (2014) Polycyclic aromatic hydrocarbons (PAHs) and their polar derivatives (oxygenated PAHs, azaarenes) in soils along a climosequence in Argentina. Sci. Total Environ. 473-474, 317-325. https://doi.org/10.1016/j. scitotenv.2013.12.037

Wilson S.C. and Jones K.C. (1993). Bioremediation of soil contaminated with polynuclear aromatic hydrocarbons (PAHs): a review. Environ. Pollut. 81 (3), 229-249. https://doi.org/10.1016/0269-7491(93)90206-4

Wszolek P.C. and Alexander M. (1979). Effect of desorption rate on the biodegradation of n-alkylamines bound to clay. J. Agr. Food Chem., 27 (2), 410-414. https:// doi.org/10.1021/jf60222a058

Xu S.Y., Chen Y.X, Wu W.X, Wang K.X, Lin Q. and Liang X.Q. (2006). Enhanced dissipation of phenanthrene and pyrene in spiked soils by combined plants cultivation. Sci. Total Environ. 363 (1-3), 206-215. https:// doi.org/10.1016/j.scitotenv.2005.05.030

Yang Y.Y., Wang J., Liao J.Q., Xie S.G. and Huang Y. (2014). Distribution of naphthalene dioxygenase genes in crude oil-contaminated soils. Microbial Ecology 68 (4), 785-793. https://doi.org/10.1007/s00248-0140457-7

Zhong W.H. and Cai Z.C. (2007). Long-term effects of inorganic fertilizers on microbial biomass and community functional diversity in a paddy soil derived from quaternary red clay. Appl. Soil Ecol. 36 (2-3), 84-91. https://doi.org/10.1016/j.apsoil.2006.12.001

Zhou X., Zhou J., Xiang X., Cébron A., Béguiristain T. and Leyval C. (2013). Impact of four plant species and arbuscular mycorrhizal (AM) fungi on polycyclic aromatic hydrocarbon (PAH) dissipation in spiked soil. Pol. J. Environ. Stud. 22 (4), 1239-1245 